\title{
İnternet Alan Adı (Domain) Uyuşmazlıklarının Çözümünde Alternatif Yöntemler: UDRP, URS ve TRABİS Karşılaştırması
}

\author{
Alternative Methods for Resolving Internet Domain Name Disputes: A \\ Comparative Review of the UDRP, the URS and the TRABIS
}

\author{
Mehmet Bedii Kaya* iD
}

\section{öz}

Alan adları (domainler), internet ortamında yer alan bir içeriği pratik olarak konumlandırmak amacıyla kullanılan kısa yollardır. Alan adları, belge değişimi veya fiziksel temasın kısıtlı olduğu, kimlik teyidinin olmadığ1 otomatikleştirilmiş bir süreçle gerçekleştirilmektedir. İnternetin ticari amaçla kullanımının öne çıkmasıyla birlikte alan adlarının maddi değeri artmıştır. Bunun bir neticesi olarak, başkalarına ait markalarla aynı veya benzer nitelikteki alan adlarını yüksek bir meblağ karşılığında satmak, marka sahibinin alan adını kullanmasını engellemek, alan adının esasen ticari rakiplerin işlerine ya da faaliyetlerine zarar vermek, alan adıyla karışıklık meydana getirmek suretiyle başka siteye yönlendirmek gibi kötü niyetli davranışları içeren cybersquatting olarak da adlandırılan yeni bir haksız fiil türü ortaya çıkmıştır. İnternet ortamında markadan kaynaklanan hakların etkin korunması için ICANN tarafından iki uyuşmazlık çözüm mekanizması geliştirilmiştir: Uniform Domain Name Dispute Resoultion Policy (UDRP) ile Uniform Rapid Suspension (URS). Ayrıca, ülke kodlu üst düzey alan adları için farklı ülkeler kendi özel uyuşmazlık çözüm usûllerini devreye almıştır. Örneğin, Türkiye TR üst düzey alan adı için TRABİS isimli müstakil bir uyuşmazlık çözüm usûlü geliştirmiştir. Bu çalışmada, UDRP ve URS usûlleri etraflıca incelenecektir. UDRP ve URS incelemesinden sonra ise TR üst düzey alan adları için uygulamaya alınacak olan TRABİS usûlü incelenecektir. Çalışmanın amacı TR alan adlarına ilişkin getirilen uyuşmazlık çözüm mekanizmasının uluslararası kurallarla ne kadar benzeștiği ve ne oranda farklılaştığını ortaya koymaktadır.

Anahtar Kelimeler: Alan Adı, Uyuşmazlık, Marka, Haksız İşgal, UDRP, URS, TRABİS

* Dr. Öğr. Üyesi, İstanbul Bilgi Üniversitesi Hukuk Fakültesi Bilişim ve Teknoloji Hukuku Ana Bilim Dalı, ORCID: 00000001-5256-9854

Sorumlu Yazar/Correspondence Author: Mehmet Bedii Kaya

E-posta/E-mail: mehmet@mbkaya.com

Geliş Tarihi/Received: $\quad$ 15.09.2021

Kabul Tarihi/Accepted:

14.11.2021 


\section{ABSTRACT}

Domain names are practical shortcuts that are used to locate Internet content. Domain names are registered through automated processes in which document exchange or physical contact is limited and does not require identity verification. As a consequence of the commercialisation of the Internet, the financial value of domain names has substantially increased. Hence, a new type of tort, so-called cybersquatting, has emerged, which is comprised of the registration of a domain name in bad faith primarily for the purpose of selling, renting or otherwise transferring it for valuable consideration; in order to prevent the owner of the trademark from reflecting the mark in a corresponding domain name; primarily for the purpose of disrupting the business of a competitor; in order to intentionally attract commercial gain by creating a likelihood of confusion with the trademark. Two dispute resolution mechanisms have been developed by ICANN for effective protection of trademark rights on the Internet: Uniform Domain Name Dispute Resolution Policy (UDRP) and Uniform Rapid Suspension (URS). Furthermore, various countries have developed their own special dispute resolution procedures for country code toplevel domains. For example, Turkey has developed a stand-alone dispute resolution procedure called TRABIS for the TR top-level domains. In this study, the UDRP and URS methods will be analysed in detail. After the UDRP and URS review, the TRABIS will be scrutinised. The main objective of this article is to map out the similarities of the TRABIS with the UDRP and URS and distinguish the sui generis features of the TRABIS.

Keywords: Domain, Dispute, Trademark, Cybersquatting, UDRP, URS, TRABIS

\section{GiRiş}

Alan adları (domainler) internet ekosisteminin en kritik bileşenleridir. IP adreslerinin kullanımının pratik olmaması sebebiyle önceleri bir internet ağında bir içeriğe alternatif erişim yöntemi olarak geliştirilen alan adları, artık internet ortamında gezinmenin ve bilgiye erişmenin en temel aracı haline gelmiştir. ${ }^{1}$

Alan adlarının tescili kural olarak belge değişimi veya fiziksel temasın kısıtlı olduğu, kimlik teyidinin olmadığı otomatikleştirilmiş bir süreçle gerçekleştirilmektedir. Beyan usûlüne göre işleyen ve otomatikleştirilmiş bu süreç sayesinde alan adlarının sayısı bu denli artmaktadır. Bazı alan adı uzantılarında kimliği teyit veya mesleği teyit için belge talep ediliyor olsa da genel kural belgesiz, otomatik tescildir. Yılda 300 milyonu aşkın alan adı kaydedilmektedir.

Alan adları, hiyerarşik olarak yapılandırılmıştır ve bu hiyerarşinin en üstünde top-level domain olarak adlandırılan üst düzey alan adları yer almaktadır. Üst düzey alan adları, sınırlı sayı prensibine göre internetin yönetiminden sorumlu kurum olan İnternet Tahsisli Sayılar ve İsimler Kurumu (ICANN) tarafından kararlaştırılmış kurallara göre belirlenmiştir.

Alan adları jenerik (generic top-level domain names) ve ülke kodlu (country code top-level domain names) olmak üzere iki temel kategoride yapılandırılmıştır. Her alan adı için asgari bir nokta (.) işaretine ihtiyaç bulunmaktadır. Alan adında noktanın sağında kalan kısım uzantı (top-level domain),

1 DNS olarak da adlandırılan bu sistemin tarihsel gelişimi için bkz. Johnny Ryan, A history of the Internet and the digital future, Reaktion Books, 2010, 100. 
solunda kalan kısım ise (second-level domain) olarak adlandırılmaktadır. Bu şekilde alan adları hiyerarşide konumlanabilmektedir.

İnternetin ticari amaçla kullanımının öne çımasıyla birlikte alan adları özel bir maddi değeri haiz olmuştur. Alan adları marka olarak tescil edilmeye başladığı gibi, markaların da alan adı olarak alınması ve kullanılması gibi durumlar ortaya çıkmıştır. ${ }^{2}$ Bunun bir neticesi olarak da başkalarına ait markaları satmak amacıyla alan adı olarak tescil eden veya satmak amacı olmaksızın salt marka sahibinin kendi markasına ilişkin alan adlarını kullanmasını engellemek için tescil eden yeni bir haksız fiil türü ortaya çıkmıştır.

Cybersquatting olarak adlandırılan bu kötü amaçlı tescil ve kullanım internet ekosisteminin en büyük tehditlerinden birisidir. ${ }^{3} \mathrm{Bu}$ tehdide karşı ve internetin dinamikliği dikkate alınarak ICANN tarafından üst düzey alan adlarına ilişkin özel iki uyuşmazlık çözüm mekanizması geliştirilmiştir: Uniform Domain Name Dispute Resolution Policy (UDRP) (Alan Adı Uyuşmazlıklarının Yeknesak Çözüm Politikası) ile Uniform Rapid Suspension (URS) (Yeknesak İvedi Askıya Alma Politikası). Ayrıca, ülke kodlu üst düzey alan adları için farklı ülkeler kendi özel uyuşmazlık çözüm usûllerini devreye almıştır. Örneğin Türkiye, TR üst düzey alan adları için TR Ağ Bilgi Sistemi (TRABİS) isimli müstakil bir uyuşmazlık çözüm usûlü geliştirmiştir.

Bu çalışmada UDRP ve URS isimli uyuşmazlık çözüm usûlleri etraflıca ele alınacaktır. Çalışmada, UDRP ve URS usûllerinin hem usûle hem de esasa ilişkin kuralları ele alınacak, iki usûl arasındaki farklar tespit edilecek ve bu çözüm usûllerinin etkinliği değerlendirilecektir. UDRP ve URS incelemesinden sonra ise TR üst düzey alan adları için uygulamaya alınacak olan TRABİS usûlü incelenecektir. Çalışmanın amacı TR alan adlarına ilişkin getirilen uyuşmazlıkçözüm mekanizmasının uluslararası kurallarla ne kadar benzeştiği ve ne oranda farklılaştığını ortaya koymaktır. Bu tespitler 1şı̆̆ğnda özellikle UDRP gibi bir usûl takip etmek yerine müstakil bir politika geliştirmenin yerindeliği sorgulanacaktır. Çalışmanın amacı ve kapsamı dikkate alınarak, fikri mülkiyet hukukuna, özellikle de markalara ilişkin derinlemesine bir tartışma yapılmayacak olup konu internet hukuku tartışmalarıyla sinırlı tutulacaktır.

\section{UNIFORM DOMAIN NAME DISPUTE RESOLUTION POLICY (UDRP) (ALAN ADI UYUŞMAZLIKLARININ YEKNESAK ÇÖZÜM POLITIKASI)}

UDRP politikası 1999 yılında ICANN tarafından yürürlüğe koyulmuştur. ${ }^{4} 2021$ yılı itibariyle, ICANN tarafından akredite edilmiş tüm alan adı tescil kuruluşları (registrar) ile belirli ülke alan

2 Alan adı ile marka arasındaki ilişki için bkz. Zeynep Yasaman, Türk ve Avrupa Birliği Hukukunda İnternette Marka Hakkının İhlali, On İki Levha Yayıncılık, 2020, 142-160.

3 İnternet ortamının düzenlenmesine ilişkin genel bir konsensüs olmasa da marka sahiplerinin güçlü bir lobiye sahip olmasının daha internetin geliştiği ilk dönemlerde marka sahiplerini koruyucu böyle kapsamlı ve bağlayıcı bir düzenlemeye imkân verdiği belirtilmektedir. Bu konuda bkz. Jacqueline Lipton, Internet Domain Names, Trademarks and Free Speech, Edward Elgar, 2010, 41.

4 ICANN, 'Uniform Domain Name Dispute Resolution Policy (UDRP)' https://www.icann.org/resources/pages/policy2012-02-25-en (Son Erişim Tarihi 22.11.2021). 
adlarını yöneten kuruluşlar tarafından uygulanmaktadır. UDRP politikasının amacı, alan adını kaydeden son kullanıcı ile bu alan adı sebebiyle hak iddiasında bulunabilecek üçüncü kişilerin arasındaki uyuşmazlıklara ilişkin usûl ve esasları belirlemektir. ${ }^{5}$ UDRP, internetin ticarileşmesinin ve alan adlarının bir mülkiyet olarak kolektif değerinin farkına varılmasının bir neticesi olarak oluşturulmuştur. ${ }^{6}$ UDRP, kendi özgün kuralları sebebiyle lex digitalis olarak da adlandırılmaktadır. ${ }^{7}$

UDRP, çerçeve bir politikadır. Alan adlarıyla ilgili kurallar, içtihatlarla ve Dünya Fikri Mülkiyet Örgütü (WIPO) ve ICANN uygulamalarıyla şekillenmektedir. ${ }^{8}$ İlk UDRP başvurusu 9 Aralık 1999 tarihinde worldwrestlingfederation.com alan adı için yapılmış olup 14 Ocak 2000 tarihinde WIPO tarafindan bu başvuru başvuran lehine karara bağlanmıştır. ${ }^{9}$

UDRP, alan adı sahipleri ile alan adı tescil kuruluşları arasında uygulanan tek düzenleme değildir. Alan adı tescil kuruluşları pekâlâ bulundukları ülkenin hukuk kurallarına veya kendi tescil politikalarına uygun şekilde ilave kurallar koyabilirler ve alan adı sahiplerine UDRP'de yer almayan ilave bir yükümlülük getirebilirler. Her halükârda bir alan adı kaydedildiği zaman kayıt yapan son kullanıcı şu beyanlarda bulunmaktadır:

(a) Kayıt sözleşmesinde paylaştı̆̆

(b) Bu alan adını kaydetmek herhangi bir üçüncü kişinin hakkına halel getirmediğini veya üçüncü kişinin hakkını başka bir şekilde ihlal etmediğini,

(c) Alan adının hukuka aykırı amaçlarla tescil edilmediğini,

(ç) Alan adını uygulanabilir herhangi bir hukuk kuralı veya düzenlemeyi ihlal edecek şekilde bilerek kullanılmadığını. ${ }^{10}$

UDRP, bir alan adına ilişkin hangi durumlarda hakiddiasında bulunabileceğini etraflıca düzenlemiştir. UDRP kapsamında bir alan adı kullanımının durdurulması veya transferinin talep edilebilmesi için şu üç koşulun birlikte gerçekleşmesi gerekmektedir: ${ }^{11}$

$5 \quad \operatorname{UDRP}(\mathrm{n}$ 4) Madde 1.

6 Kenneth Merrill, 'Domains of Control: Governance of and by the Domain Name System' in Francesca Musiani, Derrick L Cogburn, Laura DeNardis, Nanette S Levinson (Eds), The Turn to Infrastructure in Internet Governance, Palgrave Macmillan, 2016, 96; Yeni domain uzantılarının kullanıma sunulması da marka sahiplerinin haklarının etkin şekilde korunmasına yönelik politik tartışmalar sebebiyle yavaş ilerlemiştir. Bu konudaki tartışmalar için bkz. Milton Mueller, Ruling the Root - Internet Governance and the Taming of Cyberspace, MIT Press, 2002, 193.

7 Matthias C Kettemann, The Normative Order of the Internet, OUP, 2020, 219.

8 Bkz. WIPO, 'WIPO Overview of WIPO Panel Views on Selected UDRP Questions, Third Edition' (WIPO Jurisprudential Overview) https://www.wipo.int/amc/en/domains/search/overview3.0/ (Son Erişim Tarihi 16.05.2021); UDRP politikası öncesi WIPO’nun alan adları ihtilaflarına ilişkin yaklaşımı için bkz. Tekin Memiş, 'Internet Alan İsimleri Uyuşmazlıklarında Çözüm Arayışları ve WIPO Ara Raporu', 1999, 19(1-2), Milletlerarası Hukuk ve Milletlerarası Özel Hukuk Bülteni, 513-527.

9 Andrew Murray, The Regulation of Cyberspace Control in the Online Environment, Routledge-Cavendish, $2007,112$.

$10 \operatorname{UDRP}(\mathrm{n}$ 4) Madde 2.

11 UDRP (n 4) Madde 4. 
1. Alan adı, ticari bir marka veya hizmet markası ile aynı veya iltibasa mahal verecek şekilde benzer olmalıdır (identical or confusingly similar).

2. Alan adını tescil edenin, alan adıüzerinde hiçbir hakkıveya meşru menfaati bulunmamalıdır (legitimate rights or interest).

3. Alan adı, kötü niyetli olarak tescil edilmiş ve kullanılmış olmalıdır (bad faith).

Bir alan adının salt bir markayla benzer olması, alan adının sicilden terkini veya hak iddia eden kişiye transfer edilmesi için tek başına yeterli değildir. Keza meşru bir amacı olmasa bile kötü niyetli tescil ve kullanım ispat edilemezse talep neticesiz kalacaktır. Diğer bir deyişle, yukarıda sayılan üç koşul aynı anda oluşmadığı takdirde alan adına ilişkin talep başarısız olacaktır.

UDRP politikası uyarınca hak taleplerinde ispat külfeti iddia eden üzerinedir. Kişi veya kuruluş, tescil edilmiş bir alan adının ticari markasıyla aynı veya iltibasa mahal verecek şekilde benzer olduğunu; üstelik bu alan adını tescil eden kişinin alan adı üzerinde hiçbir hakkı veya menfaati olmadığını ve hem tescilin hem de kullanımın kötü niyetli olduğunu ispat etmekle yükümlüdür.

\section{A. BENZERLIK KRITERI}

Bir alan adına ilişkin UDRP politikasına göre talepte bulunabilmek için alan adının ticari bir marka veya hizmet markası ile aynı veya iltibasa mahal verecek şekilde benzer olması gerekmektedir. WIPO tarafından açıklandığı üzere, bu markanın tescilli veya tescilsiz olması veya markanın hangi hukuk düzeninde korumaya sahip olduğu da önemli değildir. ${ }^{12}$

Alan adı ihtilaflarında top-level-domain (TLD), diğer bir deyişle alan adının sonundaki com, net, org gibi kısaltmalar markaya ilişkin benzerliğin tespitinde dikkate alınmalı mıdır? Kural olarak TLD standart bir tescil koşulu olduğu için TLD uzantısının markaya ilişkin benzerlikte dikkate alınmaması gerektiği belirtilmektedir meğerki TLD bir markanın bir kısmını oluştursun. ${ }^{13}$

Markayla aynı olmak kolay şekilde çözülecek bir ihtilafken benzerliğin çözülmesi farklı parametrelerin dikkate alınmasını gerektirmektedir. Özellikle kasten yazım hataları yapılması (typosquatting), ${ }^{14}$ küçük ve büyük harf kullanımında sıkça karıştırılan harflerin kullanılması (I v 1 gibi), markanın tercümesinin kullanılması (transliteration), klavyedeki dizilişin ve yazım alışkanlıklarının taklit edilmesi gibi durumlar sebebiyle her somut olayda benzerliğe ilişkin müstakil değerlendirme

12 WIPO Jurisprudential Overview (n 8) Bölüm 1.1.

13 WIPO Jurisprudential Overview (n 8) Bölüm 1.11.1.

14 Kasperky, 'What is Typosquatting? - Definition and Explanation' https://www.kaspersky.com/resource-center/ definitions/what-is-typosquatting (Son Erişim Tarihi 16.05.2021). 
yapılması gerekmektedir. ${ }^{15}$ Alan adının bütüncül işitsel hali ve fonetik mukayesesi de bu aşamada benzerliğin tespiti için kullanılan kriterlerdir. ${ }^{16}$

\section{B. HAK VEYA MEŞRU MENFAAT KRITERI}

Bir alan adının bir markayla aynı veya iltibasa mahal verecek şekilde benzer olduğunun tespitinden sonra ispat edilmesi gereken ikinci husus alan adını tescil edenin alan adı üzerinde bir hakkı veya menfaati olmadığıdır. UDRP, hak veya meşru menfaate ilişkin yol gösterici bazı örnekler içermektedir. UDRP politikasına göre aşağıdaki durumların varlığında hak veya meşru menfaat varlığı kabul edilebilir: ${ }^{17}$

1. Uyuşmazlığa ilişkin bildirim yapılmadan önceki dönemde, alan adını kaydeden kişinin alan adı veya alan adına tekabül eden bir ismi iyi niyetli olarak mal veya hizmetlerin sunumuna yönelik mevcut kullanımı veya ispatı mümkün bir kullanım hazırlığının olması;

2. Kişinin (birey, ticari kuruluş veya diğer bir yapı olarak), herhangi bir ticaret markası veya hizmet markası olmamasına rağmen alan adı ismiyle biliniyor olması;

3. İhtilafa konu marka veya hizmet markasının ticari bir kazanç amacıyla tüketicileri yanlış şekilde yönlendirmek veya markayı veya hizmet markasını kötülemek amaçlarıyla kullanılmaksızın, alan adının meşru ticari olmayan veya adil bir kullanımının olması. ${ }^{18}$

UDRP sürecini başlatan taraf, diğer bir deyişle markanın hak sahibi, alan adını kaydeden kişinin alan adını kullanmaya yönelik hiçbir hakkı veya meşru menfaati olmadığını ispatlamakla yükümlüdür. Bir hakkın veya meşru menfaatinin olmadığının ispatı menfi vakıa ispatıdır ve benzerlik ve iltibasın ispatına göre, diğer bir deyişle müspet bir vakıanın ispatından nispeten daha zordur. ${ }^{19}$

UDRP tarafından yukarıda sayılan durumlarda dahi hak sahipliği veya meşru menfaate ilişkin mutlak bilgi, esasında alan adı sahibinin uhdesindedir. İspat külfetinin marka sahibinde olması burada bir çıkmaza yol açmaktadır.

15 Yaygın aldatma teknikleri olarak şunlar gösterilebilir: yazım yanlışı, kasten hatalı yazım, fonetik benzerlik, görsel benzerlik, kavramsal/fikri benzerlik, genel konsept benzerliği/uygulanabilir testler, bazı harflerin eklenmesi veya çıkartılması, kısaltmalar, kelimeler içerisinde rakam kullanımı, coğrafik kavram, ek kötüleyici ifadeler, ek nötr veya isimsiz kavramlar, ișaretlerle, markalarla, jenerik kavramlarla veya coğrafi kavramlarla kombine edilmiș markalar, markanın baskın olmayan kısmının silinmesi, www gibi ön-ekler veya son-ekler eklemek, özel karakterler eklemek. Bkz. Categorization of UDRP decisions administered by the CAC https://udrp.adr.eu/arbitration_platform/categorization_ of_decisions.php (Son Erişim Tarihi 22.11.2021).

WIPO Jurisprudential Overview (n 8) Bölüm 1.7.

UDRP (n 4) Madde 4.

18 Bu tür meşru menfaatlere tüketici şikâyet siteleri örnek olarak gösterilebilir.

19 Menfi vakıa “(...) hukuki sonucun, bir vakıanın mevcut olmamasına, gerçekleşmemesine veya bir süreçya da kişi hakkındaki değer yargısının somut duruma uygun olmamasına bağlandı̆̆ı durumlarda koşul vakıa (...)” olarak ifade edilmektedir. Bkz. Hakan Pekcanitez, Muhammet Özekes, Mine Akkan, Hülya Taş Korkmaz, Medeni Usul Hukuku Cilt II, On İki Levha Yayıncılık, 2017, 1629; ayrıca bkz. WIPO Jurisprudential Overview (n 8) Bölüm 2. 
Girişte belirtildiği üzere, alan adı tescil süreçleri kural olarak kimlik teyidi gerektirmeyen veya fiziksel temasın zorunlu olmadığı otomatikleştirilmiş bir süreçle gerçekleştirilmektedir. Alan adı tescillerinde gerçek bilgilerin veya güncel kişisel verilerin paylaşılması zorunlu değildir. Bunun bir neticesi olarak, hatalı ve yanlış bilgilerin alan adı sahibi kısmına girilmesi durumuyla sıklıkla karşılaşılmaktadır.

Bir alan adının kime ait olduğu nasıl tespit edilir? Bir alan adının sahibi, WHOIS olarak adlandırılan kamuya açı rehberlerde sorgulama yapılarak belirlenebilmektedir. Örneğin, https://who.is isimli web sitesinden "google.com" alan adı sorgulandığında bu alan adının kimin tarafından ne zaman tescil edildiği, tescil süresinin ne zaman sona ereceği, alan adının hangi sunucuya yönlendirildiğini gösteren sunucu bilgileri görüntülenebilmektedir. Lakin üçüncü taraflarca sunulan özel alan adı gizleme hizmetleriyle, alan adı sahibine ait bilgilerin tamamen gizlenmesi mümkündür. Proxy hizmetleri sayesinde kişisel veriler gizlenerek özel olarak oluşturulmuş maskeli bilgiler WHOIS kaydında güncellenmektedir.

UDRP süreci başlatılması durumunda bazı proxy hizmet sağlayıcılar gerçek alan adı sahibini paylaşırken bazı proxy hizmet sağlayıcılar kişisel verilerin korunması mevzuatları sebebiyle ancak UDRP sürecinde bu bilgiyi paylaşmaktadır. WHOIS bilgisinde görünen kişinin UDRP sürecinde karşı taraf olarak tanımlanması sürecin işletilmesini engellememektedir. Keza, gerçek alan adı sahibi (underlying registrant) tespit edildikten sonra düzeltme talebinde bulunularak gerçek alan adı sahibine talebin yöneltilmesi mümkündür. ${ }^{20}$

WHOIS veri tabanının özellikle kişisel verilerin korunması bağlamında tamamen kapatılması gerektiğini ileri sürenler olduğu gibi, siber suçlarla mücadele amacıyla bu sicilin daha etkin hâle getirilmesini ve kimlik doğrulama yöntemiyle alan adı kaydı yapılması gerektiğini savunanlar da vardır. Bu konudaki tartışmalar özellikle Avrupa Birliği Genel Veri Koruma Tüzüğü (General Data Protection Regulation) (“GPDR”) düzenlemesinin yürürlüğe girmesiyle daha da alevlenmiştir. ${ }^{21}$ Esasında kişisel verilerin korunması hukuku açısından, bir kişinin marka hakkının korunması için UDRP gibi alternatif uyuşmazlık çözümü sürecini başlatmak için kişisel verileri işlemesi, bir hakkın tesisi, kullanılması veya korunması için veri işlemenin zorunlu olması ve hatta veri sorumlusunun meşru menfaatleri için veri işlenmesinin zorunlu olması gibi farklı hukuki işleme sebeplerine dayandırılabilirse de bu konuda henüz tüm hakları dengeleyecek bir orta yol bulunmamıştır.

Avrupa Birliği bünyesinde ve GDPR düzenlemesine tabi olarak faaliyette bulunan alan adı tescil kuruluşları yurtdışına veri aktarımına ilişkin kısıtlamaları gerekçe göstererek WHOIS bilgilerini "REDACTED FOR PRIVACY" şeklinde kısıtlamaktadır. Bu durumda dahi Proxy hizmetlerinde olduğu gibi doğrudan UDRP sürecinin başlatılması mümkün olacaktır.

Peki, marka sahibi alan adı kim tescil ettiğini bilmeden o kişinin bir hak sahibi olmadığı veya meşru menfaati olmadığını nasıl ispat edecektir? İspat külfetinin marka sahibi üzerinde olması teknik olarak yerinde midir?

20 WIPO Jurisprudential Overview (n 8) Bölüm 4.4.1.

21 ICANN, 'Data Protection/Privacy Issues' https://www.icann.org/dataprotectionprivacy (Son Erişim Tarihi 22.11.2021). 
UDRP sürecinde keşif yapılmamaktadır. Hakem veya hakemler kendilerine sunulan belgeler üzerinden karar vermektedir. Menfi ispatın (proving a negative) güçlügünü dikkate alan WIPO, yerleşik içtihatları da dikkate alarak alan adını tescil eden kişinin bu alan adına ilişkin hakkı veya menfaati olmadığını ispat edici temel deliller ortaya koyabilirse, ispat külfetinin karşı tarafa, alan adını tescil eden kişinin üzerine geçeceğini kabul etmektedir. ${ }^{22} \mathrm{Bu}$ şekilde marka sahibi prima facie bir bilgi veya belgeyle ispat külfetine ilişkin yukarıda izah edilen çıkmazdan bir nebze olsun kurtulmaktadır.

\section{KÖTÜ NIYET KRITERI}

Alan adı ihtilaflarında üçlü testin son aşaması kötü niyetin ispatıdır. Kötü niyetin ispatı için objektif bir kriter geliştirilmesi mümkün değildir. Yine de UDRP’de kötü niyetin ispatı için karinelere yer verilmiştir: $:^{23}$

1. Alan adının, ticaret veya hizmet markası, ticaret unvanı, işletme adı veya kişi adı ya da diğer tanitıcı işaretin sahibi olan şikâyetçiye veya şikâyetçinin ticari olarak rekabette bulunduğu tarafa, bu alan adının belgelenmiş tahsis masraflarını ve yatırım maliyetini aşan miktardaki bir meblağ karşllığında satma veya devretme amacıyla tahsis ettirilmiş olması,

2. Alan adının, ticarette kullanılan marka, ticaret unvanı, işletme adı ya da diğer tanıtıcı işaretin sahibinin, bu marka, unvan, ad ya da işareti alan adında kullanmasını engellemek amacıyla tahsis ettirilmiş olması,

3. Alan adının, esasen ticari rakiplerin işlerine ya da faaliyetlerine zarar vermek amacıyla tahsis ettirilmiş olması,

4. İhtilaf konusu alan adının, ticari kazanç elde etmek amacıyla, şikâyetçinin sahibi olduğu ticarette kullanılan marka, ticaret unvanı, işletme adı ya da diğer tanıtıcı işaret ile benzerlik oluşturup karışıklık meydana getirerek internet kullanıcılarının alan adı sahibinin internet sitesine veya herhangi bir internet sitesine yönlendirilmesi amacıyla kullanılması.

UDRP politikasına göre marka sahibinin ispat etmesi gereken kötü niyet iki boyutludur: tescilde kötü niyet ve kullanımda kötü niyet. Dolayısıyla ispat külfeti hem tescili hem de kullanımı kapsamaktadır.

Alan adının tescil edilip hiç kullanılmadığı, herhangi bir web sitesi oluşturulmadığı, hatta bir web sitesine isim sunucularının yönlendirilmediği durumlarda kötü niyetin ispatı önemli bir sorundur. Böyle bir durumda alan adını tescil edenin kötü niyetini ispat etmeye yönelik somut bir veri olmadı̆̆ için UDRP uygulamasında ciddi tartışmalar yaşanmaktadır.

22 WIPO Jurisprudential Overview (n 8) Bölüm 2.1.

23 UDRP (n 4) Madde 4; Kötü niyete ilişkin kapsamlı bir inceleme için bkz. Ayça Zorluoğlu, 'Alan Adlarında Kötü Niyet Kavrami', 2012, 2(1) 2012, Hacettepe Hukuk Fakültesi Dergisi, 67-84. 
WIPO, "pasif elde tutma doktrini" (passive holding doctrine) olarak nitelendirdiği bu durumda UDRP içtihatlarından yola çıkarak yine de kötü niyetin ortaya koyulabileceği görüşündedir. ${ }^{24}$ WIPO’ya göre, her bir UDRP uyuşmazlığında şu hususlar pasif elde tutma doktrini için kullanılabilecektir:

1. Müştekinin markasının, ihtilafa konu alan adıyla ayırt ediciliğinin ve markanın bilinirliğinin derecesi;

2. Şikâyet edilenin herhangi UDRP başvurusuna yanıt vermemesi veya iyi niyetli kullanıma ilişkin mevcut veya muhtemel bir delil sağlamaması;

3. Şikâyet edilenin kimliğini gizlemesi veya sahte iletişim bilgileri kullanması (ki bu durum alan adı tescil anlaşmasının da ihlalidir)

4. Herhangi bir iyi niyetin ortaya koyulmasının mantıksızlığı.

Pasif elde tutma doktrini için her somut olayın özelliklerinin değerlendirilmesi gerekmektedir. ${ }^{25} \mathrm{Bu}$ doğrultuda, bu doktrinin içtihatlarla gelişimi UDRP hakemlerinin alan adı uyuşmazlıklarında takdir yetkisini geniş kullandıklarının bir göstergesidir.

\section{Ç. UDRP USÛLÜ}

UDRP uyuşmazlıkları ICANN tarafından akredite edilen kuruluşlar nezdinde çözüme kavuşturulmaktadır. Marka sahibi, markasını tescil ettiği ülke veya fiilen faaliyet gösterdiği bölgeyle bağlı olmaksızın dilediği kuruluş nezdinde süreci başlatma yetkisini haizdir. ICANN tarafından yetkilendirilmiş güncel kuruluşlar şunlardır:

1. Arab Center for Dispute Resolution ${ }^{26}$

2. Asian Domain Name Dispute Resolution Centre ${ }^{27}$

3. Canadian International Internet Dispute Resolution Centre (CIIDRC $)^{28}$

4. The Czech Arbitration Court Arbitration Center for Internet Disputes ${ }^{29}$

5. National Arbitration Forum ${ }^{30}$

6. $\mathrm{WIPO}^{31}$

24 WIPO Jurisprudential Overview (n 8) Bölüm 3.3.

25 Bu doktrinin kullanıldığı güncel bir örnek için bkz. WIPO Arbitration and Mediation Center, Administrative Panel Decision, Ferrari S.p.A v. Contact Privacy Inc. Customer 124.767.6738/Warren Welsh, Revolution.app Case No. D20203537. Bkz. https://www.wipo.int/amc/en/domains/decisions/text/2020/d2020-3537.html (Son Erişim Tarihi 22.11.2021)

26 Arab Center for Dispute Resolution, http://acdr.aipmas.org/default.aspx (Son Erişim Tarihi 22.11.2021).

27 Asian Domain Name Dispute Resolution Centre, https://www.adndrc.org (Son Erişim Tarihi 22.11.2021).

28 Canadian International Internet Dispute Resolution Centre (CIIDRC), https://ciidrc.com (Son Erişim Tarihi 22.11.2021).

29 The Czech Arbitration Court Arbitration Center for Internet Disputes, https://adr.eu/index.php (Son Erişim Tarihi 05.06.2021).

30 National Arbitration Forum, https://www.adrforum.com/domain-dispute (Son Erişim Tarihi 05.06.2021).

31 WIPO, https://www.wipo.int/portal/en/ (Son Erişim Tarihi 05.06.2021); WIPO, ilk yetkilendirilen UDRP kuruluşudur. WIPO, BM ve ABD arasında devam eden internetin yönetimine ilişkin süregelen politik gerilimde bir nevi hakem olarak 
UDRP başvurusu otomatik ihtiyati tedbir içermektedir. UDRP başvurusu yapıldığı andan itibaren iki gün içerisinde alan adına transfer yasağ 1 koyulmaktadır. Başvuru yapıldıktan sonra usûli ilk inceleme yapılır ve hakem atama süreci gerçekleştirilir. Tek hakem veya üçlü hakem heyeti seçimine göre uyuşmazlık çözüm maliyeti 2000 dolar ile 5000 dolar arasında değişmektedir. UDRP yargılaması İngilizce dışında dillerde de yapılmaktadır ve başvuruda beş bin kelimeye kadar içeriğin sunulması mümkündür.

UDRP kararları kesindir ve bu kararlara karşı bir itiraz mercii yoktur. Verilen karar neticesinde talep kabul edilerek alan adı ya transfer edilmekte ya da talep reddedilerek koyulan otomatik transfer yasağı kaldırılmaktadır.

\section{UNIFORM RAPID SUSPENSION (URS) (YEKNESAK IVEDI ASKIYA ALMA POLITIKASI)}

UDRP sürecinin başlatılması alan adının kullanımına bir kısıtlama getirmemektedir. İnceleme süresince alan adının transfer edilmesi yasaklanmakla birlikte bu otomatik ihtiyati tedbir alan adı kullanılarak internet ortamında yayın yapılmasına engel olmamaktadır. Alan adı, ancak nihai hakem kararıla iptal edilmekte veya transfer edilmektedir.

UDRP alan adları uyuşmazlıklarının çözümü için önemli katkılar sunsa da çok etkin bir usûl değildir. $\mathrm{Bu}$ prosedür yaklaşık iki ay sürmektedir. Keza UDRP maliyetli bir süreçtir ve her bir alan adı için yaklaşık 5000 dolara yakın bir maliyete katlanmak gerekmektedir.

Yeni üst düzey alan adları uzantılarının (new TLDs) kullanıma sunulmasıyla birlikte internet ortamında marka haklarının korunmasına ilişkin daha dinamik bir yönteme olan ihtiyaç belirgin hale gelmiştir. 2010 yılında yeni alan adı uzantılarının kullanılmaya başlanmasıyla birlikte alan adları ihtilaflarının çözümü için ICANN tarafından 2013 yılında Uniform Rapid Suspension ("URS") isimli yeni bir usûl getirilmiştir. ${ }^{32}$ Nihayetinde yeni uzantılarda özel koruma mekanizmaları geliştirilmiş olsa da (sunrise sürecinde marka koruması gibi) binlerce uzantı alternatifinin olması sebebiyle ihtilaflar kaçınılmaz hale gelmiştir.

URS sürecinin getirilmesiyle birlikte UDRP kaldırılmamıştır. Her iki usûl de yürürlüktedir ve aynı anda uygulanmaktadır. Alan adlarının tescili ve kullanımıyla haklarının ihlal edildiğini ileri süren kişiler dilerlerse UDRP dilerlerse URS yöntemlerini ayrı ayrı veya beraber işletebilirler. ${ }^{33}$ Belirtmek gerekir ki ne UDRP ne de URS usûllerinin kullanılması bir mahkeme veya makam nezdinde hak aramaya halel getirmemektedir. Bu usûller internet hukukuna özgü usûllerdir.

Tipkı UDRP başvurusu gibi URS başvurusunun da başarıyla neticelenmesi için markanın benzer veya iltibasa yol açacak nitelikte olması, alan adını tescil edenin alan adına ilişkin bir hakkı veya

görülmüştür. Roxana Radu, Negotiating Internet Governance, Oxford University Press, 2019, 91.

32 ICANN, 'Uniform Rapid Suspension System (URS)' https://newgtlds.icann.org/en/applicants/urs/procedure-01mar13en.pdf (Son Erişim Tarihi 21.05.2021).

33 WIPO Jurisprudential Overview (n 8) Bölüm 4.22. 
meşru menfaatinin olmaması ve hem tecilin hem de kullanımın ispatlanması gerekmektedir. ${ }^{34}$ Hem UDRP hem URS benzer kurallar getirmektedir. URS usûlünün UDRP usûlünden ayrıldığı temel nokta ispat külfetine ilişkindir.

UDRP, başvurucuya katı bir ispat külfeti yüklerken URS nispeten daha hafif bir ispat külfeti getirmektedir. Şöyle ki, URS başvurusunda "açık ve ikna edici deliller" ortaya konulduğu takdirde başvurucu lehine bir karar alınabilecektir. ${ }^{35}$ URS sürecinin sonunda alan adı ne transfer edilmektedir ne de sicilden terkin edilmektedir. URS usûlüyle bir alan adının tescil süresince geçici olarak durdurulmasını sağlanmaktadır. Duruma göre bu askıya alınmanın bir yıl kadar daha uzatılması mümkündür. Bu sebeple, nispeten daha hafif bir ispat külfetiyle alan adından kaynaklanan hukuka aykırılığın önlenmesi için özel bir tedbir alınması mümkün olabilmektedir. UDRP süreci sekiz hafta sürebilirken URS süreci üç haftada neticelenebilmektedir. Bazı durumlarda hakemler kararlarını daha kısa sürede de açıklayabilmektedir.

Bir alan adına ilişkin aynı anda hem UDRP hem de URS usûllerinin işletilmesi mümkündür. UDRP kararı verilmeden evvel URS kararının verilmesi mümkündür. Peki, URS kararı UDRP hakemleri için bağlayıcı mıdır?

Yukarıda belirtildiği üzere UDRP ve URS süreçlerinin esasa ilişkin kuralları aynı olsa da ispat kuralları başta olmak üzere usûle ilişkin düzenlemeleri farklıdır. WIPO, her iki sürecin de bağımsız süreçler olduğundan hareketle URS kararlarının UDRP için bağlayıcı olmadığı görüşündedir. ${ }^{36}$ Esasında, UDRP esas dava, URS internet hukukuna özgü bir ihtiyati tedbir niteliğindedir. Bu sebeple, WIPO’nun yaklaşımı yerindedir.

URS, info, org, pro, tel, asia gibi yeni jenerik üst düzey alan adlarıyla pw gibi bazı ülke kodlu üst düzey alan adlarına uygulanmaktadır. 2021 yılı itibariyle üç kuruluş URS hizmet sağlayıcı olarak ICANN tarafından yetkilendirilmiştir. Bu kuruluşlar şunlardır:

- $\quad$ Asian Domain Name Dispute Resoultion Centre (ADNDRC) $)^{37}$

- $\quad \mathrm{MFSD}^{38}$

- $\quad$ National Arbitration Forum (NAF) ${ }^{39}$

Önceki bölümde belirtildiği üzere UDRP, uyuşmazlık çözüm usûlü olarak alternatif bir yöntem olarak geliştirilmiştir. Ancak zamanla baş edilmesi gereken alan adı sayısı arttığı için UDRP de nispeten pahalı bir yöntem olmuştur. Bu yüzden URS usûlü özel olarak tercih edilmeye başlanmıştır.

34 URS (n 32) Bölüm 8.

35 Orijinal metin: "The burden of proof shall be clear and convincing evidence." Bkz. URS (n 32) Bölüm 8.2.

36 WIPO Jurisprudential Overview (n 8) Bölüm 4.22.

37 ADNDRC, https://www.adndrc.org (Son Erişim Tarihi 10.05.2021).

38 MFSD, https://urs.mfsd.it (Son Erişim Tarihi 17.06.2021).

39 ADR Forum, https://www.adrforum.com (Son Erişim Tarihi 17.06.2021). 
UDRP usûlünün aksine URS yöntemi nihai bir hukuki çare değil; geçici bir tedbir niteliğindedir. URS kararının sonunda alan adı transfer edilmez, sadece tescil süreci boyunca askıya alınır. URS kararlarına UDRP kararlarının aksine itiraz mümkündür. Aynı usûlle kararın gözden geçirilmesi talep edilmektedir.

Şekli açıdan da URS usûlü farklılıklar içermektedir. UDRP usûlünü işletmek için İngilizce dışında da başvuru kabul edilirken URS sadece İngilizce dilinde gerçekleşmektedir. Keza UDRP başvurusunda beş bin kelimeye kadar başvuru dilekçesi sunulabilirken URS başvurusu beş yüz kelime ile sınırlıdır.

Özetle, URS yeni alan adı uzantılarına ilişkin geçici bir koruma sağlamak adına geliştirilmiş bir usûldür. Her ne kadar kısıtlı bir koruma da sağlasa, özellikle binlerce yeni alan adı uzantılarına karşı markaları korumak adına yine de önemli katkılar sunmaktadır.

\section{III. ÜLKE KODLU ALAN ADLARINDA UYUŞMAZLIK ÇÖZÜMLERi}

UDRP jenerik tüm üst düzey alan adlarında, URS ise sadece yeni üst düzey alan adlarında uygulanmaktadır. Her devletin, kendi ülke kodlu üst düzey alanında dilediği uyuşmazlık çözüm kurallarını uygulamak konusunda takdir yetkisi vardır. ${ }^{40}$

Belirtmek gerekir ki UDRP genel kabul gören bir uyuşmazlık çözüm mekanizması halini almıştır. Bu sebeple, bazı devletler kendi kurallarını uygulamak yerine UDRP usûlünü uygulamayı tercih etmişlerdir. ${ }^{41}$ Dolayısıyla, bu tercihte bulunmuş ülke kodlarında aynı şekli usûl ve esaslara göre uyuşmazlıklar çözülecektir ve kararlar bağlayıcı olarak uygulanacaktır.

Bazı devletler ise kendi uyuşmazlık çözüm mekanizmalarını geliştirmişlerdir. Bu tür politikalar da incelendiğinde genel olarak UDRP politikasından ilham alındığı ancak uyuşmazlıkların yerel mahkemelerce veya hakemlerle çözüldüğü görülmektedir. Örneğin, Rusya UDRP benzeri bir politika geliştirmiş ancak uyuşmazlığın çözümünde Rus mahkemeleri yetkili kılınmıştır. ${ }^{42}$

40 Farklı ülkelerin üst düzey alan adlarına ilişkin kapsamlı bir inceleme için bkz. Tamer Soysal, İnternet Alan Adları Hukuku (Domain Name Law), Adalet, 2014, 625 vd.

41 Bkz. AC (Ascension Island), AE and تاراما (United Arab Emirates), AG (Antigua and Barbuda), AI (Anguilla), AO (Angola), AS (American Samoa), AU (Australia), BM (Bermuda), BO (Bolivia (Plurinational State of)), BR (Brazil), BS (Bahamas), BZ (Belize), CC (Cocos Islands), CD (Democratic Republic of the Congo), CH (Switzerland), CO (Colombia), CR (Costa Rica), CY (Cyprus), DJ (Djibouti), DO (Dominican Republic), EC (Ecuador), ES (Spain), EU (European Union), FJ (Fiji), FM (Micronesia (Federated States of)), FR (France), GD (Grenada), GE (Georgia), GT (Guatemala), HN (Honduras), IE (Ireland), IO (British Indian Ocean Territory), IR (Islamic Republic of Iran), KI (Kiribati), LA (Lao People’s Democratic Republic), LC (Saint Lucia), LI (Liechtenstein), MA (Morocco), MD (Republic of Moldova), ME (Montenegro), MP (Commonwealth of the Northern Mariana Islands), MW (Malawi), MX (Mexico), NL (Netherlands), NR (Nauru), NU (Niue), PA (Panama), PE (Peru), PH (Philippines), PK (Pakistan), PL (Poland), PM (St Pierre and Miquelon), PN (Pitcairn Islands), PR (Puerto Rico), PW (Palau), PY (Paraguay), QA and (Qatar), RE (Reunion Island), RO (Romania), SC (Seychelles), SE (Sweden), SH (St Helena), SL (Sierra Leone), SO (Somalia), TF (French Southern Territories), TJ (Tajikistan), TM (Turkmenistan), TT (Trinidad and Tobago), TV (Tuvalu), TZ (United Republic of Tanzania), UG (Uganda), VE (Venezuela (Bolivarian Republic of)), VG (Virgin Islands (British)), WF (Wallis and Futuna Islands), WS (Samoa), YT (Mayotte).

42 Sergey Vasiliev, Sergey Medvedev, 'Russia: Resolving domain name disputes and doing business online in Russia' https:// www.worldtrademarkreview.com/online/russia-resolving-domain-name-disputes-and-doing-business-online-russia 
Bazı devletler tamamen kendilerine özgün kurallar geliştirirken bazı devletlerin ise hiçbir uyuşmazlık çözüm mekanizması yoktur. ${ }^{43}$ Bu sebeple de bu alan adları siber saldırganlar tarafından özellikle istismar edilmekte, bu durum ise ciddi olarak eleștirilmektedir.

\section{TR ALAN ADI}

Türkiye'de alan adları 5809 sayılı Elektronik Haberleşme Kanununda ("E-Haberleşme Kanunu”) düzenlenmiştir. ${ }^{44} \mathrm{E}-\mathrm{Haberleşme} \mathrm{Kanunu,} \mathrm{alan} \mathrm{adı} \mathrm{sistemini} \mathrm{"okunması} \mathrm{ve} \mathrm{akılda} \mathrm{tutulması} \mathrm{kolay} \mathrm{olan}$ ve genelde aranan adres sahipleri ile ilişkilendirilebilen simgesel isimlerle yapılan adreslemede, karşıllğı olan internet protokolü numarasını bulan ve kullanıcıya veren sistem" olarak tanımlamıștır.

5809 sayılı Kanun, T.C. Ulaştırma ve Altyapı Bakanlığına internet alan adlarına ilişkin strateji ve politikalar ile internet alan adlarının tahsisini yapacak kurum veya kuruluşun tespiti ile alan adı yönetimine ilişkin usûl ve esasları belirlemek görev ve yetkisi verirken, Bilgi Teknolojileri ve İletişim Kurumuna ("BTK") siber güvenlik ve internet alan adları konularında genel bir yetki vermiştir.

TR Alan adı, ICANN tarafından yapılan yetkilendirmeyle Orta Doğu Teknik Üniversitesi (“ODTÜ”) tarafından Nic.tr ismiyle yönetilmekte ve TR alan adlarının tahsisine ilişkin kurallar TR Alan Adları Politikalar, Kurallar ve İşleyiş kurallarına göre düzenlenmekte iken 2010 yılında Ulaştırma ve Altyapı Bakanlığı (o zamanki adıyla Ulaştırma Bakanlı̆̆) yayımlanan İnternet Alan Adları Yönetmelik (“TR Yönetmeliği”) ve İnternet Alan Adları Tebliği (“TR Tebliği”) ${ }^{45}$ uyarınca yeni bir rejime geçiş yapılmıştır. Yönetmeliğin, Geçici 1. maddesi uyarınca ODTÜ’nün Nic.tr sistemini BTK'ya devretmesi ve TR alan adının tamamen BTK tarafından işletilecek .tr ağ bilgi sistemi (“TRABİS”) üzerinden yönetilmesi kararlaştırılmıştır. ${ }^{46}$

\section{A. GENEL ESASLAR}

TR uzantısı hem "a.b.tr" hem "a.tr" şeklinde yapılandırılmıştır. Örneğin, google.com.tr gibi bir üst düzey alan adının uzantısı gibi kullanım mümkün olduğu gibi tsk.tr gibi müstakil kullanım da mümkündür. Hangi formatta olursa olsun TR Yönetmeliğinin 4. maddesinde yer alan ve aşağıda sayılan ilkeler uygulanacaktır:

(Son Erişim Tarihi 24.05.2021).

43 Örneğin, .us, .uk ve .ca gibi ülke kodlu alan adlarında özel kurallar uygulanmaktadır. US alan adı için uyuşmazlık çözüm mekanizması için bkz. usTLD Disputes https://www.adrforum.com/domain-dispute/ustld (Son Erişim Tarihi 25.05.2021).

44 RG 10.11.2008/27050 (Mükerrer).

45 RG 21.08.2013/28742.

46 Belirtmek gerekir ki bu geçiş süreci muhtelif hukuki ihtilafları da beraberinde getirmiştir. Danıştay On Üçüncü Dairesinin 26/12/2018 tarihli ve Esas No:2012/3549; Karar No:2018/4450 sayılı kararı ile Yönetmeliğin Geçici 1. maddesinin üçüncü fikrasının iptaline karar verilmiştir. Daha sonra Danıştay On Üçüncü Dairesinin Esas No:2019/789; Karar No:2019/2861 sayılı kararı ile iptal kararının bozulmasına karar verilmiştir. Tüm bu ihtilafların çözümlenmesini müteakip, TR alan adlarının BTK tarafından yönetimi ICANN tarafından 2019 yılında onaylanmıştır. 
1. Objektif nedenler aksini gerektirmedikçe niceliksel ve niteliksel devamlılık, ayrım gözetmeme, düzenlilik, verimlilik, nesnellik, orantılılık, şeffaflık, kaynakların etkin kullanılması ve teknoloji bağımsız davranılması,

2. Serbest ve etkin rekabet ortamının sağlanması ve korunması,

3. Tüketici haklarının korunması,

4. Hizmet kalitesinin yükseltilmesinin teşvik edilmesi,

5. Uluslararası uygulamaların ve standartların dikkate alınması,

6. Alan adlarına yönelik uygulamaların ülke koşullarına uygun, etkin ve uzun vadeli çözümler olmas1,

7. Makul koşullarda, kolaylıkla faydalanılabilecek uygulamaların teşvik edilmesi,

8. Gerçek ve tüzel kişilerin talep ettikleri hizmet dışında herhangi bir hizmeti satın almak zorunda birakilmaması,

9. ÜÇüncü kişilerin haklarının korunması.

\section{B. USÛLI ESASLAR}

TR uzantısında bazı alan adları ilk gelen alır kuralına göre tahsis edilirken bazı uzantılar belge ibrazına dayalı olarak tahsis edilmektedir. ${ }^{47}$ Alan adı bir defada en az bir en fazla beş yıl süre için tahsis edilebilmektedir.

İnternetin Türkiye'de hayatın her alanında temel bir bilgiye erişim ve haberleşme mecrası olarak kullanılmasının ve bilgi toplumuna dönüşümde dijital hizmetlerin kesintisiz olarak sunulmasının önemini dikkate alarak 5809 sayılı Kanun, alan adlarına ilişkin özel bir muafiyet getirmiştir. Kanunun 'Haczedilmezlik ve haberleşme hizmetlerinin sürekliliği' başlıklı 34. maddesi uyarınca internet alan adları gibi intifa ve kullanım hakları ile işletmecilerin yetkilendirmeleri hiçbir şekilde haczedilemez. Öte yandan TR Yönetmeliğinin 13. maddesi uyarınca alan adları satılabilir veya devredilebilir. Keza, gerçek kişilerin ölüm, gaiplik, gaiplik karinesi gibi durumlarda da alan adı yasal mirasçllara devredilebilir.

47 Belgeli tahsis edilen alt alan adları şunlardır: "av" Avukatlar, hukuk büroları ve avukatlık ortaklıkları; "bel” İçişleri Bakanlı̆̆ı kayıtlarında yer alan belediyeler; ".dr" Tip doktorları, doktor ortaklıkları; ".edu” Yükseköğretim Kurulu (YÖK) tarafından tanınan yüksek öğretim kurumları; “'gov” Kamu kurum ve kuruluşları; “.pol” Emniyet Genel Müdürlüğü ve bünyesindeki birimler; “.k12” Millî Eğitim Bakanlığı (MEB), MEB’e bağlı veya MEB tarafından onaylanmış okul öncesi eğitim veren kuruluş, ilköğretim, lise ve dengi öğretim kurumları ile Aile, Çalışma ve Sosyal Hizmetler Bakanlığının ilgili mevzuatı kapsamında onaylanmış özel kreş, gündüz bakımevi, özel çocuk kulübü gibi kuruluşlar; ".tsk" Türk Silahlı Kuvvetleri bünyesinde yer alan birimler; ".kep” BTK tarafından yetkilendirilen Kayıtlı Elektronik Posta Hizmet Sağlayıcıları. 
TR uzantısı için aleni bir WHOIS, diğer bir deyişle rehberlik hizmeti de sunulmaktadır. Rehberlik hizmeti bilgilendirme amaçlıdır ve TRABİS vasıtasıyla BTK tarafından işletilmektedir. Rehberde asgari olarak; tahsisli alan adı, birincil ve ikincil ad sunucuların isimleri, ilgili kayıt kuruluşu bilgileri, tahsis tarihi, tahsis süresinin bitiş tarihi, alan adı sahibinin adı, adresi ve e-posta adresi ile rehber bilgisinin güncellenme tarihi yer almaktadır.

6698 sayılı Kişisel Verilerin Korunması Kanunu’nun yürürlüğe girmesiyle birlikte rehberlik hizmetlerine ilişkin kurallar da revize edilmiştir. ${ }^{48}$ TR Tebliğinin 29. maddesinin üçüncü fıkrası uyarınca, gerçek kişi alan adı sahiplerinin kişisel verileri, rehberde ancak açık rızalarıyla yayınlanacaktır. Alan adı sahibinin açık rıza vermemesi durumunda yukarıda belirtilen bilgiler rehberde yer almayacaktır. Öte yandan gerçek kişi olmayan alan adı sahiplerinin açık rızası aranmaksızın tüm bilgileri rehberde yayımlanacaktır.

Peki, alan adı sahibine meşru bir iletişim kurulması gereken durum varsa bu nasıl gerçekleşecektir? TR Yönetmeliği bu durumlar için jenerik alan adları için de uygulanan bir nevi WHOIS proxy hizmeti sunulmasını öngörmektedir. TR Yönetmeliğinin 29. maddesinin üçüncü fikrasına göre kayıt kuruluşu, rehberdeki e-posta adresi alanında yayımlanmak üzere anonimleştirilmiş bir e-posta adresi belirleyerek bunu alan adı sahibine ve TRABİS’e bildirmekle yükümlüdür. Bu adrese gelen e-postalar kayıt kuruluşu tarafından alan adı sahibine ait e-posta adresine yönlendirilecektir.

TR Yönetmeliğinin 29. maddesi de kişisel verilerin korunmasına ilişkin ilave bir tedbir getirmektedir. Kişisel verilerin rehberde alenileştirilmesi neticesinde bu verilerin amaç dışı kullanımını önlemek adına rehberde sorgulama yapan kişiler edindikleri bilgileri istem dışı elektronik posta göndermek, ticari faaliyette bulunmak gibi amaçlarla kullanmayacağını taahhüt edeceklerdir.

\section{HAK VE YÜKÜMLÜLÜKLER}

TR uzantısında hak ve yükümlülükler BTK, kayıt kuruluşları ve alan adı sahipleri için ayrı ayrı tanımlanmıştır.

\section{BILGI TEKNOLOJILERI VE ILETIŞIM KURUMU (BTK)}

TR uzantısının yönetiminde en temel görev BTK’ya verilmiştir. TR Yönetmeliğinin 14. maddesi uyarınca BTK, alan adı tahsis ve yenilemesine ilişkin ücretler ile uyuşmazlık çözüm mekanizmasının işletilmesi ile ilgili işlemlere ilişkin ücretleri belirlemek, gerektiğinde değişiklik yapmak ile TRABİS’i kurmak ve işletmek veya belirlediği usûl ve esaslar çerçevesinde TRABİS’in üçüncü bir tarafça kurulması ve işletilmesini sağlamakla görevlidir. Aynı doğrultuda, tahsise açılacak veya kullanımına son verilecek alt alan adlarını belirlemekle ilgili de BTK görevlidir. TR uzantısının beraberçalışabilirliğini ve küresel erişilebilirliğini de temin etmek amacıyla ICANN, RIPE NCC, CENTR gibi kuruluşlar nezdinde gerekli koordinasyonu da BTK sağlamakla görevlidir.

RG 17.10.2020/31277. 
BTK’nın alan adları ihtilaflarını da çözmeye yönelik önemli bir görevi vardır. BTK, alan adları ile ilgili ihtilafların çözüm sürecini hakemler veya hakem heyetleri vasıtasıyla yürüten taraflar olarak tanımlanan uyuşmazlık çözüm hizmet sağlayıcılarını (UÇHS) belirlemekle görevlidir. Keza, alan adı ihtilaflarına ilişkin kendisine iletilen mahkeme kararlarını ve UÇHS’nin kendisine ilettiği ihtilafa konu olan alan adları ile hakem veya hakem heyeti kararlarını, kişisel verilerin korunması amacıyla gerekli önlemleri de alarak internet sitesinde güncel olarak bulundurmak da BTK’nın görevleri içerisindedir.

\section{KAYIT KURULUŞU}

TRABİS sisteminde alan adı kayıtları kamulaştırılmamıştır. Bilakis, ICANN’in jenerik alan adı uzantılarına ilişkin metodolojisini takip edilerek, BTK’nın “kayıt kuruluşu” olarak tanımlanan uluslararası karşılığı registrar kuruluşları üzerinden alan adı tescillerini yönetmesi öngörülmüştür.

TR alan adları BTK’nın gözetim ve denetimi altında özel kişilerce gerçekleştirilmektedir. Başvuru, yenileme, iptal gibi alan adları ile ilgili işlemlerin yapılmasına aracılık eden taraflar kayıt kuruluşu olarak tanımlanmıştır. BTK’nın da sınırlı olarak kayıt kuruluşu olarak hareket etme yetkisi vardır.

TR Yönetmeliğinin 17. maddesi kayıt kuruluşlarına farklı nitelikte yükümlülükler getirmektedir. Bu yükümlülükler şu şekilde sınıflandırılabilir:

1. Siber güvenliği sağlama ve erişilebilirliği temin etme yükümlülüğü

2. Veri kalitesini ve güncelliğini sağlama yükümlülüğü

3. Uyumluluk yükümlülüğü

4. Özen yükümlülüğü

5. Şeffaflık yükümlülüğü

6. Veri yerelleştirme yükümlülüğü

7. İşlem kayıtlarını muhafaza yükümlülüğü

8. Yetkili hakem ve mahkeme kararlarını icra etme yükümlülüğü

Kayıt kuruluşunun ilk temel yükümlülüğü güvenliğe ilişkindir. Kayıt kuruluşu kullandığı cihaz ve sistemler ile sunduğu hizmetlerin erişilebilirliğini, güvenliğini, güvenilirliğini, bütünlüğünü sağlamakla yükümlüdür. Aynı doğrultuda, sunduğu hizmetlerin kalitesi ve sürekliliği ile ilgili bir aksamanın yaşanmamasını sağlamakla ve bunun için yeterli sayıda nitelikli personel çalıştırmak ve gerekli teknik donanıma sahip olmakla yükümlüdür. Tüm bu altyapı yatırımını yapan ve gerekli personel istihdamını sağlayan kayıt kuruluşunun, kişilere sundukları hizmetlere yedi gün 24 saat eşit erişim imkânı sağlaması beklenmektedir. 
Kayıt kuruluşunun ikinci yükümlülüğü veriye ilişkindir. Kayıt kuruluşuna bu bağlamda kapsamlı ve detaylı bir veri kalitesini sağlama ve güncelleme yükümlülüğü getirilmiştir. TR Yönetmeliğinin 17. maddesi uyarınca kayıt kuruluşu, alan adı başvurusu ve diğer işlemler sırasında kişilerden tam ve doğru bilgiler almakla, bu bilgilerin güvenliğini ve gizliliğini sağlamakla, bu bilgileri güncellemekle, asgari yıllık olarak teyit etmekle, bilgi değişikliklerini TRABİS üzerinden BTK'ya derhal bildirmekle, bu bilgileri BTK ve yasal olarak yetkili kılınan taraflar haricinde hiçbir tarafa vermemekle ve alınma amaçları dışında kullanmamakla yükümlüdür. Bu yükümlülüklerin bir yansıması olarak, alan adı kayıt başvuru formunun tam ve doğru olarak doldurulmaması halinde alan adı başvurusunun kabul edilmeyeceği düzenlenmiştir.

Kayıt kuruluşunun üçüncü yükümlülüğü teknik işleyişe ve hizmet kalitesine ilişkindir. Kayıt kuruluşu, kendisine yapılan alan adına ilişkin tahsis, yenileme, iptal gibi talepleri gerçek zamanlı ve TRABİS’te uygulanan yazılım standartlarına uygun olarak TRABİS’e iletmekle yükümlüdür. Keza, kayıt kuruluşu TRABİS üzerinden yürüttükleri alan adına ilişkin işlemleri yerine getirirken gerekli özeni göstermekle yükümlüdür.

Kayıt kuruluşunun TR Yönetmeliği uyarınca muhtelif şeffaflık yükümlülükleri vardır. Öncelikle kayıt kuruluşu, tanıtıcı bilgilerini, ilgili mevzuatı ve başvuru formunun örneğini kendisine ait ".tr" uzantılı alan adına sahip İnternet sitesinde ilgili tarafların ulaşabileceği şekilde ve güncel olarak bulundurmakla yükümlüdür. Bu yükümlülüğün yan sıra, kendisinden hizmet alan ve almak isteyen kişileri; alan adına ilişkin başvuru, tahsis, yenileme, iptal, transfer gibi işlemlerle ilgili olarak bilgilendirmekle ve rehberlik hizmetine (WHOIS sorgusu) kendi İnternet siteleri üzerinden ücretsiz erişim imkânı sağlamakla yükümlüdür. Ayrıca, her yıl Mart ayı sonuna kadar bir önceki yıla ait faaliyet raporunu BTK’ya sunmakla yükümlüdür.

Kayıt kuruluşunun bir diğer yükümlülüğü ise işlem kayıtlarını muhafaza yükümlülüğüdür. Kayıt kuruluşu bu doğrultuda alan adı ile ilgili işlemler dolayısıyla elde ettiği bilgi ve belgeleri alan adının kullanımının herhangi bir nedenle sona ermesinden itibaren en az 10 yıl süre ile saklamakla yükümlüdür.

Kişisel verilerin korunması mevzuatlarıyla daha sık rastlanan veri yerelleştirme politikalarının alan adı sektörüne de yansımaları olmuştur. TR Yönetmeliğinin 17. maddesi uyarınca kayıt kuruluşu, TRABİS’e entegre olan sistemlerini ve yedeklerini Türkiye Cumhuriyeti sınırları içinde bulundurmakla yükümlüdür.

Kayıt kuruluşunun son yükümlülüğü ise alan adı ihtilaflarına ilişkindir. ${ }^{49} 2021$ yllında TR Yönetmeliğinin 17. maddesinin birinci fikrasına eklenen (l) bendi uyarınca kayıt kuruluşu, alan adı ihtilaflarına ilişkin kendisine iletilen mahkeme kararları ile UÇHS’nin kendisine ilettiği ihtilafa

49 .tr uzantısında kayıt kuruluşlarına yönelik yükümlülükler getirilmiş olsa da hukuka aykırılıktan dolayı doğrudan sorumlulukları bulunmamaktadır. Kayıt kuruluşları, nötr olarak hareket etmesi internetin uluslararası bilgi ağı niteliğine uygun bir yaklaşımdır. Öte yandan alan adlarına ilişskin hak koruma mekanizmalarına kayıt kuruluşlarının da sorumlu tutulabileceği bazı özel durumlar vardır. Trademark Post-Delegation Dispute Resolution Procedure (PDDRP) olarak adlandırılan bu prosedür için bkz. Yasaman (n 2) 168. 
konu olan alan adlarına ilişkin hakem veya hakem heyeti kararlarının gereğini yerine getirmekle yükümlüdür.

\section{ALAN ADI SAHIBI}

TR Yönetmeliği, alan adlarını kaydeden kişileri "alan adı sahibi” olarak tanımlanmakta ve alan adı sahiplerine bazı haklar tanırken bunlara karşılık da bazı yükümlülükler getirmektedir. ${ }^{50} \mathrm{TR}$ Yönetmeliğinin 21. maddesi uyarınca alan adı sahibi, alan adını tahsis süresi boyunca kullanma, alan adı tahsisini yenileme, alan adından feragat etme, hizmet aldığı kayıt kuruluşunu değiştirme haklarına sahiptir.

TR Yönetmeliği’nin 22. maddesi ise alan adı sahibine yükümlülükler getirmektedir. Söz konusu hükme göre alan adı sahibi, ilgili mevzuata uymakla, kayıt kuruluşuna tam ve doğru bilgiler vermekle, bu bilgilerde meydana gelen değişiklikleri derhal hizmet aldığı kayıt kuruluşuna bildirmekle, üçüncü kişilerin haklarını ihlal etmemekle ve kayıt kuruluşları arası zorunlu transfer hallerinde bilgilendirilmesini müteakip gereken işlemleri yapmakla yükümlüdür.

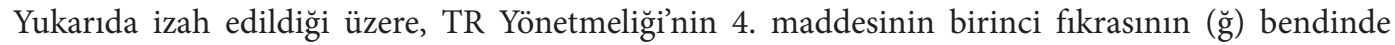
üçüncü kişilerin haklarının korunması temel bir ilke olarak kabul edilmiştir. Alan adı sahipleri de üçüncü kişilerin haklarını ihlal etmemekle yükümlü tutulmuşlardır.

$\mathrm{Bu}$ ilke ayrıca 7. maddeyle de perçinlenmiştir. Kayıt kuruluşları, alan adı kaydı yapacak kişileri başvuru sırasında, yanlış bilgi verme, üçüncü kişilerin haklarını ihlal etme gibi fiillerin hukuki sonuçları konusunda genel olarak bilgilendirmekle yükümlüdürler. Aynı doğrultuda, kişilerin başvuru sırasında, üçüncü kişilerin haklarını ihlal etmeyeceklerini, alan adını hukuka aykırı bir şekilde kullanmayacaklarını ve iptal veya feragat durumunda bu işlemlerin kendi lehlerine bir hak doğurmayacağını kabul ettiklerini beyan ve taahhüt etmeleri zorunludur.

\section{TR ALAN ADI UYUŞMAZLIKLARININ ÇÖZÜMÜ}

\section{A. USÛLE ILIŞKIN KURALLAR}

TR Yönetmeliği, tr uzantılı alan adlarına ilişkin ihtilafların çözümü için alternatif bir uyuşmazlık çözüm sistemi oluşturmuştur. TR Yönetmeliğine istinaden çıkarılmış İnternet Alan Adları Uyuşmazlık Çözüm Mekanizması Tebliği (“TR Uyuşmazlık Tebliği”) 51 de uyuşmazlıkların çözümüne ilişkin detayları düzenlemiştir. Bu Tebliğde hüküm bulunmayan hallerde BTK’nın kurul kararı ile düzenleme yapma yetkisi bulunmaktadır.

50 Alan adı sahibi ifadesi yerinde bir tercih midir? Doktrinde haklı olarak belirtildiği üzere "alan adını tahsis ettiren taraftan "alan adı sahibi" yerine, "alan adını kayıt ettiren" olarak bahsedilmesi, alan adları hukukuna daha uygun düşen bir terim olurdu. Çünkü "sahiplik" meşru bir hakkı ve malikliği barındırır oysa alan adını kayıt ettiren taraf her zaman meşru bir hakka sahip olmayabilir." bkz. Soysal (n 40) 746; Benzer bir eleştiri için bkz. Oğuz Sefer, İnternet Alan Adı (Domain Name) Haklarının Korunması, Seçkin, 2014, 470.

51 RG 21.08.2013/28742. 
TR Yönetmeliği’nin 23. maddesi uyarınca alan adları ile ilgili ihtilaflar alternatif olarak UÇHS’ler tarafından işletilen uyuşmazlık çözüm mekanizması vasıtasıyla çözülecektir. Bu bağlamda, ICANN ile benzer bir usûl izlenmiştir. Uyuşmazlıkların UDRP usûlünde olduğu gibi BTK tarafından akredite edilmiş müstakil merkezlerde çözülmesi öngörülmüştür.

UÇHS’ler bünyelerine fikri mülkiyet hakları hukuku, marka hukuku, ticaret hukuku veya bilişim hukuku alanlarında uzman olan hakemleri dahil edeceklerdir ve hakemler, uyuşmazlık konusu alan adına ve taraflarına ilişkin bağımsızlık ve tarafsızlıklarını gösterir yazılı beyanlarını UÇHS’ye sunmalarını müteakip çalışmaya başlayacaklardır.

TR Yönetmeliği hakem kararları için de özel bir şeffaflık hükmü getirmektedir. TR Yönetmeliğinin 27. maddesinin ikinci fıkrası uyarınca UÇHS, kendisine iletilen kararı bir gün içinde Kuruma, şikâyetle ilgili taraflara ve ilgili kayıt kuruluşlarına bildirmek ve internet sitesinde yayımlamak zorundadır. Kararların UDRP uygulamasındaki gibi şeffaf şekilde yayınlanması bu alandaki içtihatların oluşması açısından da önemli bir faktördür.

UÇHS’lere aynı anda birden fazla alan adı için başvuruda bulunulması mümkündür. Bu konuda UDRP ile benzer bir usûl geliştirilmiştir.

UÇHS’lere yapılacak başvuru ücrete tabidir. Bu ücret, BTK tarafından belirlenecek üst sınıra göre UÇHS’ler tarafından tespit edilecektir. BTK’nın gerektiğinde uyuşmazlık çözüm mekanizmasının işletilmesi ile ilgili işlem ücretlerine ilişkin alt sınırı da belirleyebilme yetkisi vardır. Uyuşmazlık Tebliğinin 20. maddesi uyarınca her bir hakem için hakem ücreti, 1000 Türk Lirasıdır. Bu ücret her yıl bir önceki yıla ilişkin olarak T.C. Hazine ve Maliye Bakanlığınca belirlenecek yeniden değerleme oranına göre artırılacaktır. UÇHS ücreti ise her bir hakem için belirlenen ücretin yarısıdır.

TR Yönetmeliğinin 26. maddesinin üçüncü fıkrası uyarınca hakemlerin çalışmalarını kendilerine iletilen bilgi, belge ve delillerden oluşan dosya üzerinden yapmaları esas olup gerek görülmedikçe, tarafların şahsen dinlenmeyeceği düzenlenmiştir. Bu şekilde, ihtilafların hızla çözülmesi hedeflenmektedir.

Uyuşmazlık Tebliğinin 13. maddesi uyarınca hakemin veya hakem heyetinin, ihtiyaç duyması halinde UÇHS vasıtasıyla taraflardan ek bilgi ve belge isteme yetkisi saklıdır. Bu durumda dahi uyuşmazlığa ilişin karar dosya üzerinden verilmektedir.

Şikâyetçinin ya da şikâyet edilen tarafın hakeme ya da hakem heyetine doğrudan bilgi ve belge sunması yasaklanmıştır; taraflar arası bilgi ve belge akışı sadece UÇHS vasıtasıyla yapılacaktır. Uyuşmazlık Tebliği, UÇHS ve taraflar arası iletişimin e-posta gibi elektronik yöntemlerle de sağlanabilmesine imkân tanımaktadır.

Uyuşmazlık Tebliği’nin 18. maddesi uyarınca taraflarca aksi kararlaştırılmadıkça, uyuşmazlık çözüm sürecinde kullanılacak dil Türkçedir. Bilindiği üzere UDRP'de İngilizce dilinde de uyuşmazlık çözümü süreci yürütülebilmektedir. TR alan adları için mutlak bir yasak getirilmeyip tarafların aksini kararlaştırmasına izin verilmesi yerinde bir yaklaşımdır. 
Uyuşmazlık Tebliğìnin 7. maddesinin altıncı fıkrasının (ç) bendi uyarınca UÇHS’ye yapılacak başvuruda, şikayetçinin iddiasını destekleyici tüm bilgi ve belgeler ile beş bin kelimeyi aşmayacak şekilde başvuru şartlarının sağlandığına ilişkin gerekçeler yer almak zorundadır. ${ }^{52}$ Şikayetçi, aynı şikâyet konusu ile ilgili olarak daha önce başka bir UÇHS'ye veya mahkemeye başvuruda bulunup bulunmadığını ve alınmış herhangi bir karar olup olmadığını da beyan etmek zorundadır. Şikâyet edilen de cevabında konu ile ilgili olarak daha önce başka bir UÇHS'ye veya bir mahkemeye başvuruda bulunulup bulunulmadığı ve alınmış herhangi bir karar olup olmadığı bilgisini vermek zorundadır. Her iki düzenleme de UDRP ile paraleldir.

UÇHS'ye yapılacak başvuru üzerine hakem veya hakem heyeti, ilgili mevzuat, içtihatlar ve yargı kararlarını da göz önüne alarak şikâyetçi tarafın talebi doğrultusunda alan adlarının iptaline, şikâyetçi tarafa devrine veya şikâyetçi tarafın talebinin reddine karar verecektir. Hakem kurulunun kararları basit çoğunlukla alınmaktadır ve çekimser oy kullanılması mümkün değildir. Alan adının transferine karar verilebildiği için UDRP benzeri bir düzenleme yapılmıştır. Alan adıyla ilgili icrai bir karar verilmektedir.

Uyuşmazlık Tebliğinnin 14. maddesi uyarınca hakem veya hakem heyetinin, şikâyet dilekçesi ve cevabı sürecinin tamamlanmalarını müteakip on beş gün içinde karar vermesi gerekmektedir. Bu süre içerisinde karar verilememesi durumunda hakemin ya da hakem heyetinin beş güne kadar ek süre kullanması mümkündür. Uyuşmazlığın temelde on beş gün içerisinde karara bağlanmasının zorunlu tutulmasıyla, internet alan adları ihtilaflarının hızla çözülmesi ve bu şekilde internet ortamındaki hizmetlerin sürdürülebilirliğinin temin edilmesi amaçlanmıștır. Bu süre, UDRP süresinden daha kısa niteliktedir ve TRABİS bu yönüyle UDRP usûlünden farklılaşmaktadır.

Uyuşmazlık Tebliği’nin 15. maddesi uyarınca, hakem kararının taraflara tebliğ edilmesinden itibaren on iş günü içinde veya uyuşmazlık çözüm mekanizması sürecinin daha önceki bir aşamasında konu hakkında ihtiyati tedbir kararının alındığının UÇHS’ye bildirilmemesi halinde ilgili kayıt kuruluşu ve UÇHS tarafından TRABİS’e iletilmek suretiyle alınan kararın gereğinin derhal yerine getirilmesi gerekmektedir.

Benzer şekilde, hakem kararının taraflara gönderilmesinden sonra on iş günü içinde veya uyuşmazlık çözüm mekanizması sürecinin daha önceki bir aşamasında konu hakkında ihtiyati tedbir kararının alındığının UÇHS’ye bildirilmesi halinde uyuşmazlık çözüm mekanizması süreci devam edecektir ancak hakem ya da hakem heyeti kararı uygulanmayacaktır. Bu durumda dava sürecinin tamamlanması beklenecek ve mahkeme kararının gereği ilgili kayıt kuruluşu ve UÇHS tarafından TRABİSe iletilmek suretiyle derhal yerine getirilecektir. ${ }^{53}$

52 Bilgi ve belge kelimelerinin kullanılması doğru bir tercih olmamıştır. Doktrinde yerinde bir şekilde belirtildiği üzere "Tebliğde uyuşmazllk konusu olan veya olmayan vakıların ispatında kullanılan verilerin tümü için "bilgi ve belge" terimi kullanılmıştır. Oysa, hukuk muhakemeleri usûlü terminolojisinde mutad olan dava veya cevap dilekçesinde iddia edilen vakıanın ispatının "delil" ile yapılacă̆ıdır. Bu itibarla, dava veya cevap dilekçesindeki vakılarının ispatı için kullanılan veriler için "bilgi ve belge" ibaresi yerine "delil" ifadesinin kullamilmalddr." bkz. Oğuz (n 50) 473.

536769 sayılı Sinai Mülkiyeti Kanunu, haksız rekabet hükümleri kapsamında ve adın korunmasına ilişkin hükümler kapsamında alan adlarına ilişkin dava açlması mümkündür. RG 10.01.2017/29944. Uyuşmazlı̆̆ın dava yoluyla çözümüne ilişkin detaylı bir inceleme için bkz. Zeliha Karaman, İnternet Alan Adı Uyuşmazlıkları ve Çözüm Yolları: 
UÇHS'ye bir alan adına ilişkin başvuru yapılması durumunda, uyuşmazlığa konu olan alan adı uyuşmazlık süresince dondurulmaktadır. Bu bağlamda, alan adı kaydında yer alan bilgilerin değiştirilmesine, alan adının satışına, devrine, feragatine veya kayıt kuruluşu transferine izin verilmemekte; sadece alan adının yenilenmesine izin verilmektedir. Uyuşmazlık Tebliğinin 16. maddesiyle getirilen bu özel koruma UDRP ile benzer niteliktedir. UDRP süreci başlatıldığında da alan adına transfer yasağı koyulmaktadır. Bu şekilde uyuşmazlığın üçüncü kişilere teşmil edilmesi ve şikayetçinin de hak kaybına uğramasının önlenmesi amaçlanmaktadır.

\section{B. ESASA ILIŞKIN KURALLAR}

Usûle ilişkin UDRP’ye benzerlikler ihtilafların esasına ilişkin de gözlemlenmektedir. TR Yönetmeliğinin 25. maddesi uyarınca uyuşmazlık çözüm mekanizmasına başvuru için;

1. İhtilaf konusu alan adının, sahip olunan ya da ticarette kullanılan marka, ticaret unvanı, işletme adı ya da diğer tanıtıcı işaretlerle benzer ya da aynı olması,

2. Alan adını tahsis ettiren tarafın bu alan adı ile ilgili yasal bir hakkı ya da bağlantısının olmamasi,

3. Bu alan adının alan adı sahibi tarafından kötü niyetle tahsis ettirilmesi veya kullanılması

4. gerekmektedir.

$\mathrm{Bu}$ üç şartın birlikte sağlandığını iddia eden şikâyetçi, uyuşmazlığın çözümü için UÇHS’lerden birini tercih ederek başvurusunu yapacaktır. Belirtmek gerekir ki, şikâyetçi başvuruda bulunduğu UÇHS'nin kendisine kesin bir karar bildirmesine kadar aynı hususta başka bir UÇHS'ye başvuruda bulunamaz.

Benzerlik ve iltibas kriteri, hak veya meşru menfaat kriteri UDRP ile birebir aynı olsa da kötü niyet kriteri UDRP'den önemli bir farklılık içermektedir. TR Yönetmeliği uyarınca alan adı sahibi tarafından kötü niyetle tahsis ettirilmesi veya kullanılması alternatif hukuka aykırılık halleridir. Halbuki UDRP için hem tahsisin hem de kullanımın kötü niyetli olması gerekmektedir. Her ne kadar içtihatlarla bu konuda bazı istisnalar getirilmiş olsa da UDRP uygulamasından ders çıkarılarak "ve" yerine "veya" ibaresinin kullanılması yerinde bir yaklaşımdır.

Uyuşmazlık Tebliğinin 19. maddesinde, tıpkı UDRP usûlünde yer aldığı gibi kötü niyetin ispatına ilişkin karineler düzenlenmiştir. Müteakipteki durumlar alan adının kötü niyetle tahsis ettirilmesi veya kullanılması olarak nitelendirilecektir:

1. Şikâyet konusu alan adının, ticaret veya hizmet markası, ticaret unvanı, işletme adı veya kişi adı ya da diğer tanıtıcı işaretin sahibi olan şikâyetçiye veya şikâyetçinin ticari olarak rekabette

Karşılaştırmalı Bir Analiz, Seçkin, 2017, 112-119. 
bulunduğu tarafa, bu alan adının belgelenmiş tahsis masraflarını ve yatırım maliyetini aşan miktardaki bir meblağ karşılığında satma veya devretme amacıyla tahsis ettirilmiş olması,

2. Şikâyet konusu alan adının, ticarette kullanılan marka, ticaret unvanı, işletme adı ya da diğer tanıtıcı işaretin sahibinin, bu marka, unvan, ad ya da işareti alan adında kullanmasını engellemek amacıyla tahsis ettirilmiş olması,

3. Şikâyet konusu alan adının, esasen ticari rakiplerin işlerine ya da faaliyetlerine zarar vermek amacıyla tahsis ettirilmiş olması,

4. İhtilaf konusu alan adının, ticari kazanç elde etmek amacıyla, şikâyetçinin sahibi olduğu ticarette kullanılan marka, ticaret unvanı, işletme adı ya da diğer tanıtıcı işareti ile benzerlik sağlayarak karışılık meydana getirmek suretiyle internet kullanıcılarının alan adının internet sitesine veya herhangi bir internet sitesine yönlendirilmesi amacıyla kullanılması.

Önemle vurgulamak gerekir ki bu durumlar tahdidi olmayıp hakem veya hakem heyeti takdiri ile de alan adının kötü niyetle tahsis ettirildiği veya kullanıldığına karar verilebilecektir.

TR alan adları için öngörülen kötü niyetli tahsis veya kullanımın karineleri incelendiği zaman bunların UDRP usûlünde öngörülen karinelerle aynı nitelikte olduğu görülmektedir. Bu doğrultuda denilebilir ki, kötü niyetle hem tahsisin hem de kullanımın müstakil bir ihlal olarak kabul edilmesine ilişkin farklılık dışında UDRP ile TRABİS arasında esasa ilişkin bir fark bulunmamaktadır.

\section{SONUÇ}

Hem UDRP hem de URS usulleri, usûl ekonomisine hizmet eden pratik çözüm mekanizmalarıdır. Online şekilde, duruşmasız olarak internetin ruhuna uygun şekilde özel bir koruma sağlanmaktadır. UDRP alan adlarına yönelik özel bir ihtilaf çözüm mekanizmasıdır. Bu usûl, alan adının yöneldiği web sitesi içeriğine ilişkin ihtilafların çözüm mekanizması olarak tasarlanmamıştır. ${ }^{54}$ İçerik kötü niyetin ispatına yönelik bir delil olarak kullanılsa da hedeflenen alan adının kendisidir, içeriği değildir. Aynı doğrultuda tüm marka ihlal türleri de - örneğin markanın sulandırılması - UDRP kapsamına girmemektedir. ${ }^{55}$

UDRP, güvenilir bir uyuşmazlık çözüm mekanizması olarak yaygın olarak benimsenmiştir. ${ }^{56} \mathrm{Bu}$ sayede uyuşmazlıkların ulusal mahkemelere gitmeksizin çözülmesi mümkün olmuştur. Alan adı

54 Hannah Bloch-Wehba, 'Global Platform Governance: Private Power in the Shadow of the State', 2019 72(1), SMU Law Review, 27-80, 41.

55 Annemarie Bridy, 'Addressing Infringement: Developments in Content Regulation in the US and the DNS' in Giancarlo Frosio (Ed.), The Oxford Handbook of Online Intermediary Liability, OUP, 2019, 4.

56 UDRP usûlüne yönelik en temel eleştirilerden birisi coğrafi işaretleri korumaya yönelik etkin olmamasıdır. İnternetin küresel ağ niteliği karşısında coğrafi işaretlerin bölgeselliği bu alana özgü etkin ve pratik bir koruma rejiminin geliştirilmesini zorlaştırmaktadır. Bu konuda bkz. Theodor Georgopoulos, 'Cyberspace v Territory: Domain Names and the Problem of Protection for Geographical Indications' in Tatiana Synodinou, Philippe Jougleux, Christiana Markou, Thalia Prastitou (Eds), EU Internet Law - Regulation and Enforcement, Springer, 2017, 329. 
ihtilaflarına ilişkin mahkemelere çok kısıtlı bir başvuru yapılmaktadır. ${ }^{57}$ İnternet ortamında hukuka aykırılıklarla mücadelede konsensüs sağlanması kolay değildir. Bu sebeple, 30 yılı aşkın bir sürede markalardan kaynaklanan hakların korunması için özel bir usûlün etkin şekilde uygulanıyor olması önemli bir kazanımdır.

UDRP usûlünün büyük oranda başvurucular lehine neticelendiğinden bu usûlün başvurucular lehine olduğu için eleştirilmektedir. ${ }^{58}$ 1999-2021 ylları arası verilen UDRP kararları incelendiği zaman başvuruların \%90’nın iptal veya transfer ile neticelenirken, sadece \%10'unun reddedildiği görülmektedir. ${ }^{59}$

\begin{tabular}{|l|l|}
\hline \multicolumn{2}{|c|}{ 1999-2021 Arası UDRP İstatistikleri } \\
\hline İptal kararı & 635 \\
\hline Transfer kararı & 36530 \\
\hline Şikâyetin reddi & 4162 \\
\hline
\end{tabular}

UDRP, kişilik haklarının korunması gibi özel bir alana uygulanabilir mi? Kişilik hakları ihlallerinin marka ihlal durumlarına kıyasen tahdidi olarak belirlenmesine yönelik sorunlar ve yerel hukukların bu konudaki farklılığı dikkate alındığında UDRP gibi genel bir ihtilaf çözüm mekanizmasının geliştirilmesi kolay olmayacaktır. ${ }^{60}$

URS ise bir anda yüzlerce yeni üst düzey alan adının uygulamaya koyulmasıyla oluşan yeni düzende marka sahiplerinin etkin şekilde korunması için özel bir ihtilaf çözüm mekanizması olarak geliştirilmiştir. Daha ucuz ve daha hızlı bu usûlün uygulamaya alınmasıyla uluslararası lex digitalis daha görünür hale gelmiștir.

Hem UDRP hem URS, çerçeve politikalardır ve WIPO başta olmak üzere ilgili kurum ve kuruluşların rehberleriyle ve yeni içtihatlarla şekillenmektedir. Hakem kararlarının şeffaf şekilde yayınlanması, bu alanda hukuki belirliliğin sağlanmasına önemli katkılar sunmaktadır.

Girişte belirtildiği üzere, alan adlarının tescili kural olarak belge değişimi veya fiziksel temasın kısttlı olduğu, kimlik teyidinin olmadığı otomatikleştirilmiş bir süreçle gerçekleştirilmektedir. Beyan usûlüne göre işleyen ve otomatikleştirilmiş bu süreç sayesinde alan adlarının sayısı bu denli artmaktadır. Türkiye’de TR uzantısı ise farklı bir yaklaşımla çalışmaktadır. TR uzantılı alan adlarının tescili için istisnai uzantılar bir yana bırakılacak olursa genel olarak kapsamlı belgelendirme yükümlülüğü vardır.

TR uzantısının dayandığı katı belgeye dayalı sistem, tamamen dezavantajlı değildir. Doktrinde de haklı olarak vurgulandığı üzere: ${ }^{61}$

57 Radu (n 31) 92.

58 Bridy (n 55) 5.

59 WIPO, 'Domain Name Disputes' https://www.wipo.int/amc/en/domains/statistics/decision_rate.jsp?year=2020 (Son Erişim Tarihi 12.06.2021).

60 Joanna Kulesza, International Internet Law, Routledge, 2012, 43.

61 Hüseyin Ülgen, Mehmet Helvacı, Abuzer Kendigelen, Arslan Kaya, Füsun Nomer Ertan, Ticari İşletme Hukuku, On İki Levha, 2015, 388. 
“ODTÜ’nün alan adı tahsis ve tescil taleplerinde bugüne kadar getirdiği kurallar, Türk hukuku bakımından birçok sorunun doğmasını engeller nitelikte olmuştur. Örneğin, alan adı taleplerinin, talepte bulunan kişi ve/veya kuruluşun ismi ve/veya tescilli markası ile ilişkili olması ve bu ilişkiyi belgelemesi gerektiği kural, yukarıda belirtmiş olduğumuz türden sorunları ortadan kaldırma veya en aza indirme amacına hizmet etmiştir."

Katı belgeye dayalı sistem, ihtilaf sayısını minimize etmiştir ancak bunun bir neticesi olarak da TR uzantılı alan adlarının tescili yaygınlaşmamıştır ve hatta TR uzantılı alan adları bu sebeple Türk şirketleri tarafından tercih edilmemektedir. Dolayısıyla, avantaj bir yandan dezavantaja dönüşmektedir.

BTK ve ODTÜ arasındaki TR uzantısının yönetimine ilişkin dava neticelenmiş ve geçiş süreci başlamış olsa bile TRABİS henüz tam olarak faaliyete geçmemiştir. Teknik altyapının kurulması, kayıt kuruluşlarının yeni rejime geçişi, UÇHS’lerin kurulması ve yetkilendirilmesi süreçleri devam etmektedir. ${ }^{62}$ TRABİS düzenlemeleri, UDRP ile benzerlik taşısa da tüm sistematiğin yeterli olduğu söylenemez. ${ }^{63}$

TR uzantısı için yeni bir döneme giriş yapılırken, bu alan adlarını daha cazip hale getirmek adına katı belgeleme kurallarının esnetilmesi yerinde bir tercih olacaktır. TR uzantısını uluslararası kullanıma açmak için önemli bir fırsat niteliğindedir.

Önemle belirtmek gerekir ki, uyuşmazlık çözümünde de yerel bir uyuşmazlık çözüm mekanizması yerine diğer birçok ülkenin yaptığı gibi tamamen UDRP sisteminin benimsenmesi yerinde bir tercih olacaktır. Oturmuş içtihatlarıyla ve yaygın kullanımıyla hukuki belirliliğin sağlandığı bir çerçevenin TR uzantısı için de uygulanması, şüphesiz hem alan adları sahipleri hem de marka sahipleri için daha güvenceli bir durum olacaktır. Keza, İstanbul Tahkim Merkezi (ISTAC) gibi bir ulusal uyuşmazlık çözüm merkezinin de WIPO gibi ICANN nezdinde akredite olmasıyla ihtilaf çözümüne ilişkin de Türkiye’nin uluslararası platformda etkisi artacaktır.

Sonuç olarak, alan adlarına ilişkin ne kadar yeknesak kural varsa, suçla mücadeleden marka haklarının korunmasına kadar fayda en üst düzeye çıkartılacaktır. Türkiye’nin alan adlarına ilişkin kendi özel rejimini oluşturmak yerine uluslararası sisteme doğrudan dahil olmasının Türkiye’nin menfaatine olacă̆ı değerlendirilmektedir.

\section{KAYNAKÇA}

Bloch-Wehba H, "Global Platform Governance: Private Power in the Shadow of the State", 2019 72(1), SMU Law Review, 27-80.

62 TRABİS'in faaliyete geçmesiyle alan adlarıyla ilgili ihtilafların daha kolay çözüleceği için TR uzantılı alan adlarının daha fazla tercih edileceğine yönelik görüş için bkz. Karaman (n 53) 125.

63 TR alan adları için bir ön kayıt süresinin (sunrise period) açık bir şekilde belirtilmesi; hukukçu olmayan hakemlerin görev almasının mümkün olması; adını tahsis ettiren tarafın alan adı ile ilgili yasal bir hakkı ya da bağlantısının olmamasına ilişkin örnek hallerin belirtilmemesi gibi eksiklikler göze çarpmaktadır. Bu konuda bkz. Soysal (n 40) 747; Oğuz (n 50) $470 \mathrm{vd}$. 
Bridy A, "Addressing Infringement: Developments in Content Regulation in the US and the DNS" in Giancarlo Frosio (Ed.), The Oxford Handbook of Online Intermediary Liability, OUP, 2019.

Georgopoulos T, "Cyberspace v Territory: Domain Names and the Problem of Protection for Geographical Indications" in Tatiana Synodinou, Philippe Jougleux, Christiana Markou, Thalia Prastitou (Eds), EU Internet Law - Regulation and Enforcement, Springer, 2017.

Karaman Z, İnternet Alan Adı Uyuşmazlıkları ve Çözüm Yolları: Karşılaştırmalı Bir Analiz, Seçkin, 2017.

Kettemann M C, The Normative Order of the Internet, OUP, 2020.

Kulesza J, International Internet Law, Routledge, 2012.

Lipton J, Internet Domain Names, Trademarks and Free Speech, Edward Elgar, 2010.

Memiş T, “İnternet Alan İsimleri Uyuşmazlıklarında Çözüm Arayışları ve WIPO Ara Raporu” 1999, 19(1-2), Milletlerarası Hukuk ve Milletlerarası Özel Hukuk Bülteni, 513-527.

Merrill K, "Domains of Control: Governance of and by the Domain Name System" in Francesca Musiani, Derrick L Cogburn, Laura DeNardis, Nanette S Levinson (Eds), The Turn to Infrastructure in Internet Governance, Palgrave Macmillan, 2016.

Mueller M, Ruling the Root - Internet Governance and the Taming of Cyberspace, MIT Press, 2002.

Murray A, The Regulation of Cyberspace Control in the Online Environment, Routledge-Cavendish, 2007.

Oğuz S, İnternet Alan Adı (Domain Name) Haklarının Korunması, Seçkin, 2014.

Pekcanıtez H, Özekes M, Akkan M, Taş Korkmaz H, Medeni Usul Hukuku Cilt II, On İki Levha Yayıncilık, 2017. Radu R, Negotiating Internet Governance, Oxford University Press, 2019.

Ryan J, A history of the Internet and the digital future, Reaktion Books, 2010.

Soysal T, İnternet Alan Adları Hukuku (Domain Name Law), Adalet, 2014.

Ülgen H, Mehmet Helvacı, Abuzer Kendigelen, Arslan Kaya, Füsun Nomer Ertan, Ticari İşletme Hukuku, On İki Levha, 2015.

Yasaman Z, Türk ve Avrupa Birliği Hukukunda İnternette Marka Hakkının İhlali, On İki Levha Yayıncılık, 2020. Zorluoğlu A, “Alan Adlarında Kötü Niyet Kavramı”, 2012, 2(1) 2012, Hacettepe Hukuk Fakültesi Dergisi, 67-84. 